\author{
研 究 報 文 \\ ソルボリシスパルプ化に関する研究開発（第 7 報 ${ }^{*}$
ポリ(オキシ-2,6-ジメトキシ-1,4-フェニレン) の基本物性
}

株日本紙パルプ研究所 重本 匡史, 伊藤 和彦**

\title{
Research and Development of Solvolysis Pulping. VII. Physical Properties of Poly (oxy-2,6-dimethoxyphenylene)
}

\author{
Tadashi Shigemoto and Kazuhiko Itoh \\ Japan Pulp and Paper Research Institute
}

\begin{abstract}
Syringol, one of the products degraded from lignin, oxidatively polymerizes to poly (oxy- 2,6 -dimethoxy-1,4-phenylene) (PPOO), which is analogue of poly (oxy-2,6-dimethyl-1,4-phenylene) (PPO) available as one of engineering plastics. Physical properties of PPOO film together with PPO, poly-carbonate(PC) and polyethylenetelephthalate(PET) films were measured. PPOO film had a little higher mechanical strength, despite other properties were not so good as PPO film.
\end{abstract}

Keywords : polyoxyphenylene, polycarbonate, polyethylenetelephthelate, physical property

\section{1. 緒言}

リグニンの利用方法としては，KPリグニンのよう に熱源とするか，MP等のように紙を抄き込むことが 行われている。その他の利用方法についてなされてき た多くの研究は, 高分子のまま (一部改質して) 利用 する方向と，分解生成物を利用する方向に区分できる。 ソルボリシスパルプ化では，リグニンを水素化分解し， 蒸解溶媒を自製するとともに, 副産物としての低分子 化合物を利用する方向で研究を進めてきた。

リグニン分解物利用で留意すべき点は, ある程度の 付加価值とかなりの需要量をもつ製品を探索すること である。現在, 工業化されているのはバニリン合成で あるが, バニリンの価格はともかく, 需要量からすれ ば年間数百 $\mathrm{t}$ 程度でそう大きくはない。また, Lignol 法等のフェノールを生産する試みもあったが1), 需要 量はともかく製品価格が低すぎた。 5 大エンジニヤリ ングプラスチックの一つにポリ (オキシ-2,6-ジメチル -1,4-フェニレン）（PPO）がある。PPO は石油系の原

* 第 6 報 木材学会誌投稿中

** 現在 三菱製紙橉筑波研究所
料である 2,6-キシレノールから合成され, 耐熱性, 寸 法安定性にすぐれ, OA 機器, 自動車, 電気・電子部品 等に使用され，今後も需要の増加が見込まれている。 一方, リグニンの水素化分解生成物中に存在する ${ }^{2} シ$ リンゴールからも同じ主鎖を持つポリマー, 即ちポリ (オキシ-2,6-ジメトキシ-1,4-フェニレン) (PPOO)が 合成できることが知られている3)。PPO がエンジニヤ リングプラスチックの地位を獲得するまでには, 2,6-キシレノール以外の多くのフェノールについて検 討されてきたが, 石油系の原料からシリンゴールを得 ることが困難であることもあって, PPOOについては 熱的な性質が検討されただけ4で余り注意を払われて いない5)。ここでは, リグニン有効利用の立場から, $\mathrm{PPOO}$ フイルムの基本的な物性を PPO, ポリエチレン テレフタレート (PET), ポリカーボネート (PC) と 比較測定し, PPO 代替の可能性を検討した。

\section{2. 実験}

\section{1 試料}

Poly (oxy-2,6-dimethoxy-1,4-phenylene) (PPO) はシリンゴールから，ジエチルアミンを触媒とし，二

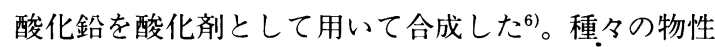


の測定は分子量 73,000（GPCによるポリスチレン換 算)のものを用いた。比較用の poly (oxy-2,6-dimethyl-1,4-phenylene) (PPO), polyethylene-telephtalate (PET), polycarbonate(PC) はArdlich 社製の市販 品を用いた。

\section{2 フイルム化}

PPOO およびPPOのフイルムは, 各ポリマーの 1,1,2,2-テトラクロロエタン溶液 $(5 \%)$ をガラス板上 に流延し, 室温で溶媒をゆっくりと蒸発させて作製し た。水中に浸漬しフイルムを自然剥離させ，その後 $100^{\circ} \mathrm{C}$ で一夜減圧乾燥させて測定に供した。両フイルム 共に透明な硬質フイルムで, PPOO は褐色, PPO は無 色であった。製膜性は共に良好で差異は認められな かった。PCおよび PET のフイルム化は溶剤に塩化メ チレンを用いて同様な方法で行った。いずれも膜厚が $50 \mu$ になるよう調節した。

\section{3 物 性 測 定}

熱物性は塊状のままセイコー電子(株)製 TG-DTA

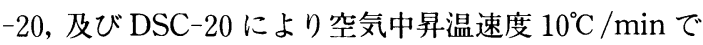
測定した。機械的性質の測定はフイルム化したサンプ ルを用い東洋ボールウイン㫼製テンシロン/UTM -4-100による $10 \mathrm{~mm} / \mathrm{min} の$ 定速度引張試験を行い, そのチャートから引張強度, 伸び及び弾性率を求めた。

抵抗率は横河ヒューレッドパッカード(株製ハイレジ

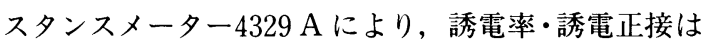
ゼネラルラジオ(株製キャパシタンスブリッヂ 1615/A により周波数 $1 \mathrm{kHz}$ で求めた。絶縁破壞電圧は原口工

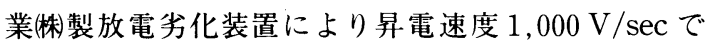

行つた。

気体透過係数の測定は, 柳本(株製ガス透過率測定装置 を用い, $30^{\circ} \mathrm{C} て ゙ 一$ 定時間後の透過ガス量をガスクロマ トグラフィーにより定量して求めた。

\section{3. 結果及び考察}

表 1 に測定結果をまとめた。

図 1 に PPOO, PPO, PCおよびPETの熱による 重量減少の様子を示した。PPOO は約 $210^{\circ} \mathrm{C}$ から分解 が始まっている。これは側鎖のメトキシル基の不安定 さに起因し，主鎖の分解はより高温で起こると考えら れる。図 2 にDSC 曲線を示した。ガラス転移点はPPO

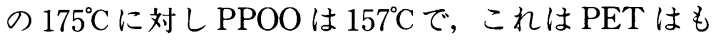
とより $\mathrm{PC}$ を回るものであり，一般的なエンジニ ヤリングプラスチックに要求される耐熱性としては充 分である。引張り強度, 弾性率はPPO を若干上回り, $\mathrm{PET}$ の半分程度であるが PC 並みである。PPOO, PPO はともに伸びの少ないフイルムであり, 硬いが粘 りの無い材料と考えられる。また, PPOOはPPO 並み の絶縁性を有し, 誘電率がやや高く, 誘電正接につい てはPC と PET の中間程度である。

最近，高分子膜による空気からの酸素分離について の研究が盛んであり, PPO は酸素富化膜の素材として も注目されている。この分野においては酸素に対する 透過性が高く, 窒素に対する酸素の選択性が大きいこ とが要求されるが, PPOO は透過係数, 選択係数とも にPPOより低い值を示した。酸素富化膜の素材とし ての応用は難しいと考えられる。また,一般のバリャー

Table 1 Physical properties of poly (oxy-2,6-dimethoxy-1,4-phenylene)

\begin{tabular}{l|c|c|c|c}
\hline \multicolumn{1}{c|}{ properties } & PPOO & PPO & PC & PET \\
\hline specific gravity $\left(25^{\circ} \mathrm{C}\right)$ & 1.23 & 1.06 & 1.20 & 1.12 \\
tensile strength $\left(\mathrm{kg} / \mathrm{mm}^{2}\right)$ & 8.3 & 7.0 & 8.5 & 15.4 \\
elongation $(\%)$ & 8 & 6 & 140 & 188 \\
elastic modulus $\left(\mathrm{kg} / \mathrm{mm}^{2}\right)$ & 243 & 191 & 240 & 333 \\
glass transition temperature $\left({ }^{\circ} \mathrm{C}\right)$ & 157 & 175 & 152 & 80 \\
beginning of thermal degradation $\left({ }^{\circ} \mathrm{C}\right)$ & 210 & 400 & 430 & 320 \\
volume resistivility $(\Omega \mathrm{cm})$ & $10^{16}$ & $10^{17}$ & $10^{16}$ & $10^{17}$ \\
surface electrical resistance $(\Omega)$ & $10^{16}$ & $10^{17}$ & $10^{16}$ & $10^{16}$ \\
dielectric breakdown voltage $(\mathrm{kV} / \mathrm{mm})$ & 132 & 163 & 150 & 234 \\
dielectric constant & 4.0 & 2.7. & 3.0 & 2.9 \\
dielectric loss tangent & 0.2 & 0.048 & 0.1 & 0.55 \\
oxygen permeability coefficient* & 2.1 & 7.5 & 2.5 & 0.028 \\
nitrogen permeability coefficient* & 0.54 & 1.6 & 0.48 & 0.0049 \\
\hline
\end{tabular}

${ }^{*} \mathrm{~cm}^{3} \cdot \mathrm{cm} / \mathrm{cm}^{2} \cdot \mathrm{sec} \cdot \mathrm{cmHg} \times 10^{10}$ 


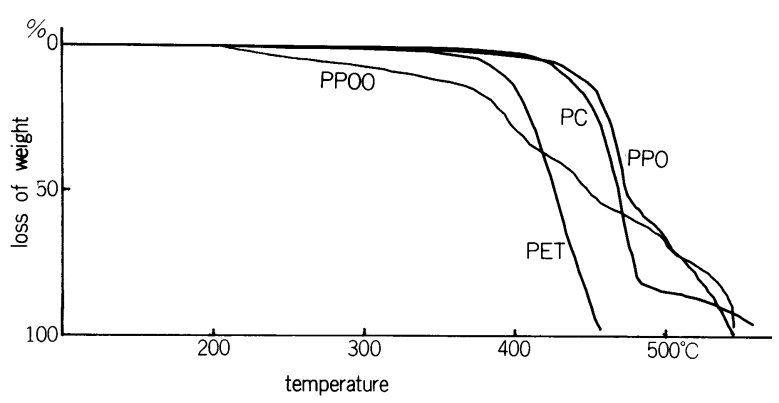

Fig. 1 TG curve of the polymers.

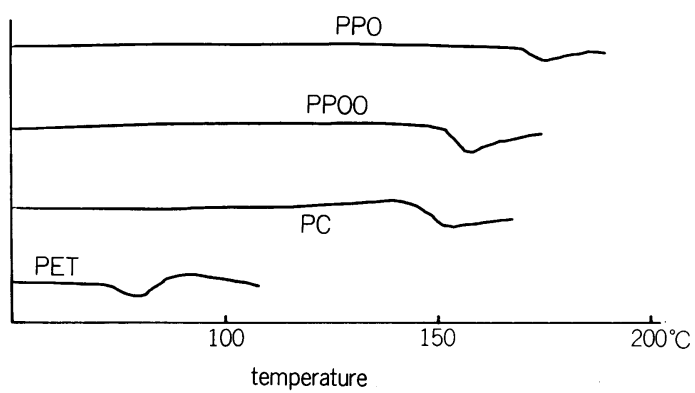

Fig. 2 DSC curve of the polymers.

フイルムとして使用するには, 酸素の透過性がやや高 い。

一般的に PPO の優れた点として, 比重が小さいこ と, ガラス転移温度が高いこと, 電気絶縁性が大きく 誘電正接が低いこと等が挙げられる。PPOOはPPO と同じ主鎖を持ち，側鎖をメチル基からメトキシル基 に変えたものである。このことによって, 熱分解の開 始温度はかなり低くなったが, 機械的性質は若干向上 した。しかし，PPO がスチレン系樹脂をブレンド，又 はグラフト化することにより耐熱性を犠牲にして成型
加工性を大幅に改良した変性樹脂として上市されてい ることを勘案すると, PPOO の熱的な性質は許容範囲 であろう。PPO よりも各段に優れた機能性はないもの の, PPOOによる $\mathrm{PPO}$ の代替の可能性は十分にある と考えられる。

\section{参考文献}

1) a ) D. G. Goheen, "Advanced in Chemistry Series (ACS)" 59, p.205

b) C \& E News, Nov.3, p. 35

2) W. Schweer, Holtzforschung, 23 ( 1 ) 5 (1969)

3) J. J. Lindberg, T. P. Jauhiainen and A. Savolainen, Pap. Puu, 54, 91 (1972)

4) T.P. Jauhiainen, Makromol. Chem., 183 $915 ; 935$ (1982)

5）“合成高分子IV” p.161 朝倉書店（1983）

6) C. R. H. I. de Jonge, H. M. van Dort and W. J. Mijs, J. Polym. Sci., Part C, 22, 431 (1968)

(受理 '89.9.19) 